\title{
In Vitro Propagation of Blackberries (Rubus sp) Prime-Ark 45 Cultivar
}

\author{
Abdrabboh, G.A; Khalifa.S.M; Abdel Aziz, H. F and El-Rashdy.A.S \\ Department of Horticulture, Faculty of Agriculture, Al-Azhar University, Nasr city, Cairo, Egypt. \\ Corresponding author: gabdrabboh65@yahoo.com
}

\begin{abstract}
This investigation was carried out to study the possibility of using in vitro technique for propagation Blackberry (Rubus sp) Prime-Ark 45 cultivar. Explants of Blackberry Prime-Ark 45 cultivar were sterilized in $0.1 \%$ of sodium hypochlorite for 15 min to get aseptic culture. In starting stage, tow explants shoot tips and axillary buds were cultured on MS media supplemented with NAA at $0.0,0.01$ and $0.1 \mathrm{mg} / \mathrm{L}$ and BA at $0.0,0.5,1.0$ and $2.0 \mathrm{mg} / \mathrm{L}$ in addition to sucrose at $3 \%$ and agar at $7 \mathrm{~g} / \mathrm{L}$. The results of starting stage showed that adding the combination between BA and NAA at 1.0 and $0.01 \mathrm{mg} / \mathrm{L}$ respectively to MS media caused the highest shoots number and shoot fresh weight compared with control and other treatments. The axillary buds were superior to shoot tips explants regarding survival percentage and other morphological characteristics. The highest shoots number and shoot fresh weight (g) were obtained when micro-shoots of tested CV., cultured on MS media supplemented with BA and KIN both at $1.0 \mathrm{mg} / \mathrm{L}$ compared with those of control and other treatments. Cytokine BA was superior to KIN regarding to mass production at multiplication stage. Halh-strenght MS media supplemented with $1.0 \mathrm{mg} / \mathrm{L}$ of NAA and IBA caused the highest root formation percentage, roots number and root length $(\mathrm{cm})$ for micro-shoots of Blackberry Prime-Ark 45 variety. IBA was superior to NAA regarding roots number and root formation percentage at rooting stage. The highest root length $(\mathrm{cm})$ was obtained when microshoots of the tested cv., were cultured on MS media supplemented with NAA at $2.0 \mathrm{mg} / \mathrm{L}$ compared with the same concentration of IBA.
\end{abstract}

[Abdrabboh, G.A; Khalifa.S.M; Abdel Aziz, H. F and El-Rashdy.A.S \} In vitro propagation of Blackberries (Rubus sp) cultivar

Key words: Micropropagation ; PGR; Auxins; Cytokinins, Sterilization, Berries

\section{Introduction}

At instant, the major commercial application of cell and tissue culture is plant propagation. Moreover, tissue culture offer additional opportunities such as rapid dissemination of new cultivars releases production of plants during the entire year rather than during limited periods. Blackberries often termed "Brambles" are a diverse group of species and hybrids in the genus Rubus. They belong to the family Rosacea. Rubus is one of the most diverse genera of flowering plants in the world and are adapted to a wide range of environments. They are native to Asia, Europe, North and South America. However, blackberries grown in specific regions are largely derived from species indigenous to that region. Blackberries have been used for eating, medicinal purposes, and as hedges to keep out marauders. In the southeastern US, Rubus sp. has been used to confer low-chilling and disease resistance into cultivars, such as Brazos and later Tupy, (Carter et al., 2006). Blackberries are rich source of anthocyanins and other polyphenolic antioxidants (Siriwoharn et al., 2004). While a large amount of fruit is sold in the fresh market, most blackberries are first processed into either individually quick frozen (IQF) fruit, puree, or juice that in turn are used as ingredients in processed products such as preservers, goods, dried products, ice cream and yogurt (Hall, 1990). Blackberries are commercially propagated by the classical methods of vegetative propagation, i.e. by hard wood and soft wood cuttings, by layering and bush division.
However, successful application of these methods of vegetative propagation is limited to a certain extent as follows Propagation by layers requires large area for a lay-bed, and weed control among the layers which is expressed as a problem. Also, Propagation by cuttings is so simple although the rooting is not always satisfactory. Soft wood cuttings root easily, but also require much attendance (Busby and Himelrick, 1998). So, micropropagation protocols were already developed for different Rubus species. Planting blackberry material of cultivars such as Marion, Black Satin, Thornless Evergreen, Loch Ness and Cacanska bestrna being produced on large scale using in vitro propagation. In most of the cases, high quantities of new blackberry plants can be produced easily, in a short period of time (Ruzic and Lazic, 2006). In vitro propagation through the development of axillary buds eliminates the seasonal limitations encountered with these methods and needs a small quantity of starting material, the in vitro plants propagated in this way in many species have proved to be healthy and true to type (Shen et al., 1990). Yazzetti et al., (2001) demonstrated that cultivar differences in chilling requirement which ranged from near 300 to $900 \mathrm{~h}$ of chilling hours below $7.2^{\circ} \mathrm{C}$. Additionally, Carter et al., (2006) reported that fruiting blackberries (Rubus $s p$.) require a period of chilling during the dormant season to resume growth in the spring has been listed as 100 to $700 \mathrm{~h}$ (hours below $7.2^{\circ} \mathrm{C}$ ). In Egypt, Farag et al., (2010) found that among the 14 Egyptian weather stations, winter chill in 2009 ranged from 510 to 995 Chilling Hours below $7.2^{\circ} \mathrm{C}$. Micropropagation 
has been recorded in great number of blackberry cultivars (Meng et al., 2004). However, micropropagation requires a great deal of experimental work on optimization of the conditions in all its phases. The main objectives of this study was to test and determine the best concentration of growth regulators added to MS media on morphogenesis, shoot multiplication and rooting of blackberries in order to produce them on large scale.

\section{Materials and Methods}

This study was carried out in the tissue culture laboratory of the Horticulture Department, Faculty of Agriculture, Al-Azhar University, Nasr City, Cairo, Egypt, during the three successive years 2018 up to 2020. Current shoots of 45 Blackberry Prime-Ark cultivar were excised from 3- year- old plants. Shoots were cleaned under running tap water for $30 \mathrm{~min}$ to eliminate dust then immerged in $70 \%$ ethanol solution for 30s. Later on the explants were sterilized in in 0.1 $\%$ mercury chloride $\left(\mathrm{HgCl}_{2}\right)$ for $3 \mathrm{~min}$, and then rinsed in distilled water $(1 \mathrm{x})$. and again sterilized by $10 \%$ sodium hypochlorite with droplets of tween 20 for 15 min. The explants were then rinsed three times in sterile distilled water. In starting stage, shoot tips with $0.1-0.5 \mathrm{~mm}$ and $3-8 \mathrm{~mm}$ length of and one node cuttings respectively were prepared and cultured on jars containing $25 \mathrm{ml}$ of Murashige and Skooge (MS) basal medium supplemented with NAA at 0.0, 0.01 and $0.1 \mathrm{mg} / \mathrm{L}$ and BA at $0.0,0.5,1.0$ and $2.0 \mathrm{mg} / \mathrm{L}$ in addition to sucrose at $3 \%$ and agar at $7 \mathrm{~g} / \mathrm{L}$. Cultures were incubated in a growth chamber at $27 \pm 2{ }^{\circ} \mathrm{C}$ under darkness condition for two weeks. The $\mathrm{pH}$ of media was adjusted at 5.7 by adding a few drops of either potassium hydroxide $(\mathrm{KOH})$ at $0.1 \mathrm{~N}$ or hydrochloric acid (HCL) at $0.1 \mathrm{~N}$. Twenty five $\mathrm{ml}$ of media were dispensed into $100 \mathrm{ml}$ glass jars. Transparent polypropylene lids were used for covering the culture jars. Then the media were sterilized by autoclaving the jars under pressure of $1.5 \mathrm{Kg} / \mathrm{cm} 2$ and at $121^{\circ} \mathrm{C}$ for 20 minutes. The jars were transferred to the culture cabinet and left to cool in a slant position till they were used. The re-cultures were conducted at each 15 days twice. The cultures were then incubated at $27 \pm 2{ }^{\circ} \mathrm{C}$ with a $16 \mathrm{~h}$ photoperiod for another two weeks. Data were collected after four weeks to measure the following measurements; shoots number, shoot length $(\mathrm{cm})$, leaves number, shoot fresh weight $(\mathrm{g})$ and survival percentage. The uniform developed shoots were excised and sub-cultured on multiplication MS media supplemented with BA and KIN both at 0.0 , $0.5,1.0$ and $2.0 \mathrm{mg} / \mathrm{L}$, sucrose at $30 \mathrm{~g} / \mathrm{L}$ and $7.0 \mathrm{~g} / \mathrm{L}$ of agar cultures were incubated in a growth chamber at $27 \pm 2{ }^{\circ} \mathrm{C}$ and exposed to a photoperiod of light $16 \mathrm{~h}$ / day and $8 \mathrm{~h} /$ day darkness, at an intensity of 1500 lux from cool white fluorescent lamps. After thirty days data of shoots number, shoot length $(\mathrm{cm})$, leaves number and shoot fresh weight $(\mathrm{g})$ were collected. Rooting stage, plantlets of Prime-Ark 45 Blackberry cultivar were transferred to Half-strength MS media supplemented with $0.0,0.5,1.0$ and $2.0 \mathrm{mg} / \mathrm{L}$ of both IBA and NAA, $15 \mathrm{~g} / \mathrm{L}$ sucrose and $1.0 \mathrm{~g} / \mathrm{L}$ of active charcoal and $7.0 \mathrm{~g} / \mathrm{L}$ of agar. Cultures were incubated in a growth chamber at $27 \pm 2{ }^{\circ} \mathrm{C}$ and exposed to the darkness for two weeks then exposed to $16 \mathrm{~h}$ photoperiod for another two weeks. Data of root formation percentage, roots number and root length (cm) were collected after four weeks. The rooted complete-plantlets were then hardened in order to acclimatization them in the greenhouse. These plantlets were washed well with water to remove the gelling material from roots and then were treated with antifungal before transferring to culture bots ex vitro contains a mixture of acid peat + vermiculite + sand $1: 1: 1$ (as a volume) in plastic trays and moisture with water. The $\mathrm{pH}$ value of this mixture was adjusted with $1.0 \mathrm{~N} \mathrm{HCl}$ or $1.0 \mathrm{~N} \mathrm{NaOH}$ to 5.7 to 5.8. Completeplantlets were cultured in small boats and enveloped with polyethylene sacs and incubated in growth incubator with light for about 50 days and then transferred to greenhouse. Statistical analysis a complete randomized block design was followed and analysis of variance (ANOVA) was performed using two ways ANOVA Co-stat software according to Stern (1991).

\section{Results and Discussions}

\subsection{Effect of Plant growth regulators on morphogenesis of Blackberry Prime-Ark 45 CV. 3.1.1. Starting stage.}

Data in Figs. From 1 up to 5 and 8 showed the effect of MS media supplemented with combination between BA at $0.0,0.5,1.0$ and $2.0 \mathrm{mg} / \mathrm{L}$ and NAA at $0.0 ; 0.01$ and $0.1 \mathrm{mg} / \mathrm{L}$; sucrose at $30 \mathrm{~g} / \mathrm{L}$ and agar at $7.0 \mathrm{~g} / \mathrm{L}$ on the morphological characteristics of Prime-Ark 45 Blackberry variety such as survival percentage; shoots number; shoot length $(\mathrm{cm})$; leaves number and shoot fresh weight $(\mathrm{g})$. It was clear that the highest survival percentage / explant achieved when axillary buds were cultured on MS media supplemented with $1.0 \mathrm{mg} / \mathrm{L}$ of BA and $0.01 \mathrm{mg} / \mathrm{L}$ NAA respectively compared with shoot tips as explants was cultured on the same previous medium. The results showed that adding combination between $\mathrm{BA}$ at $1.0 \mathrm{mg} / \mathrm{L}$ and $0.01 \mathrm{mg} / \mathrm{L}$ of NAA to the growth MS media possessed the highest shoots number; shoot length $(\mathrm{cm})$; leaves number and shoot fresh weight $(\mathrm{g})$ of Prime-Ark 45 Blackberry variety when two explants were used in comparison with those of control and other treatments. These results are agreement with Badr-Elden et al., (2016) who reported that the highest shoots number obtained when both shoot tips and axillary buds of Blackberry (Rubus fruticosus L.) were cultured on MS media supplemented with BA at 2.0 $\mathrm{mg} / \mathrm{L}$ and NAA at $0.1 \mathrm{mg} / \mathrm{L}$ compared with those of control and other treatments. Also, Fira et al., (2014) found that adding $0.5 \mathrm{mg} / \mathrm{L}$ of BA to growth medium enhanced shoots number of some blackberry 'Chester 
Thornless ', 'Čačanska Bestrna' and 'Loch Ness' cultivars compared with those of control and other treatments. The beneficial effects of BA may be due to the fact that Cytokinins promote cell division, elongation and differentiation and are also responsible for delaying the senescence of plants (Taiz and Zeiger, 2013).

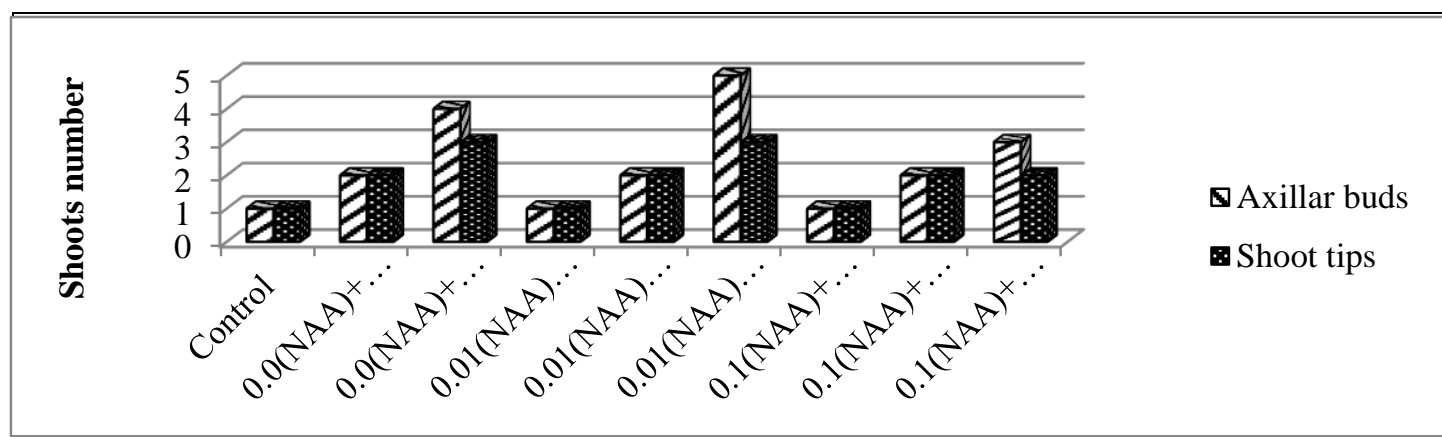

Fig.1 : Effect of MS media supplemented with BA and NAA on shoots number of Blackberry PrimeArk 45 cv., at starting stage
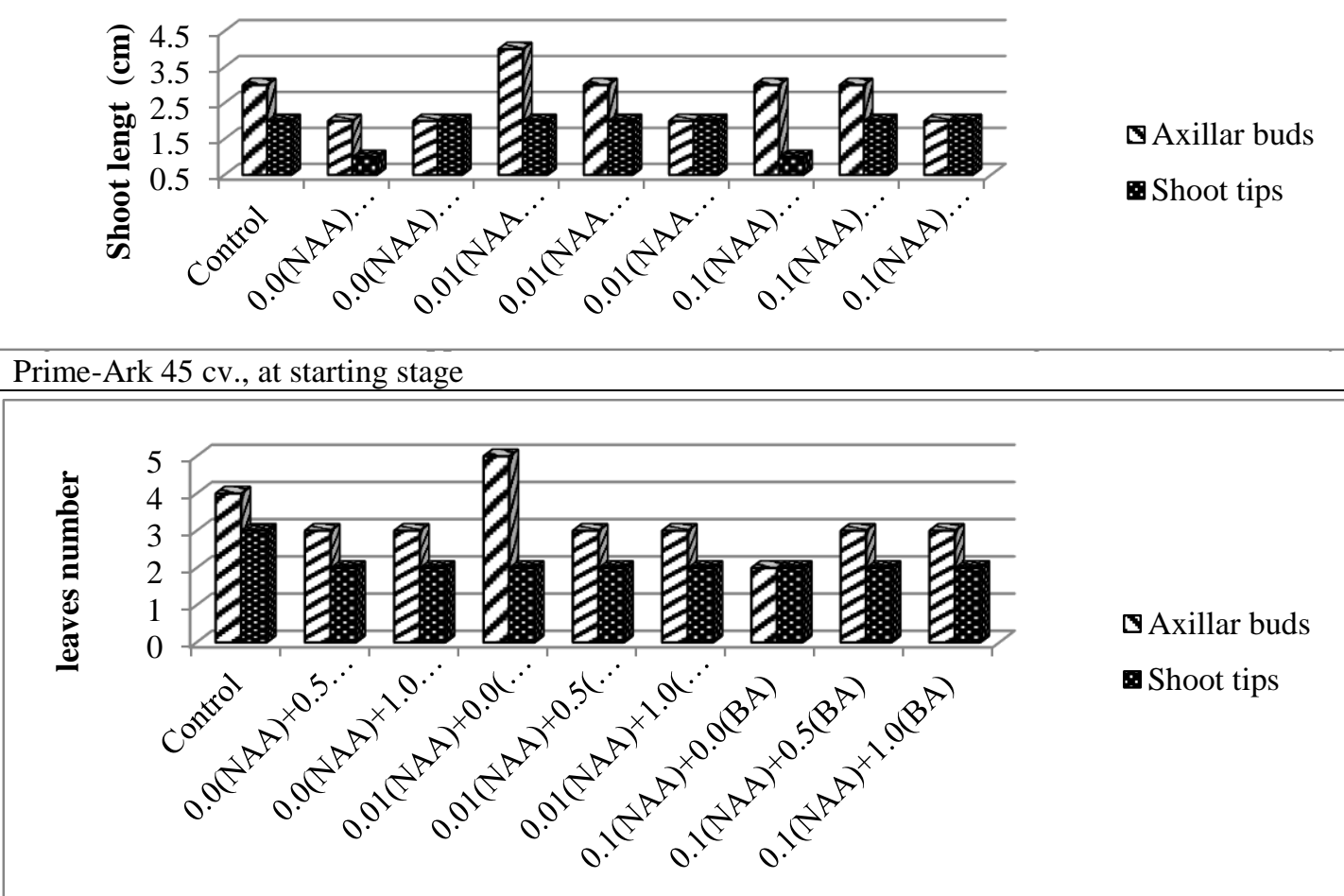

Fig.3 : Effect of MS media supplemented with BA and NAA on leaves number of Blackberry PrimeArk $45 \mathrm{cv}$., at starting stage

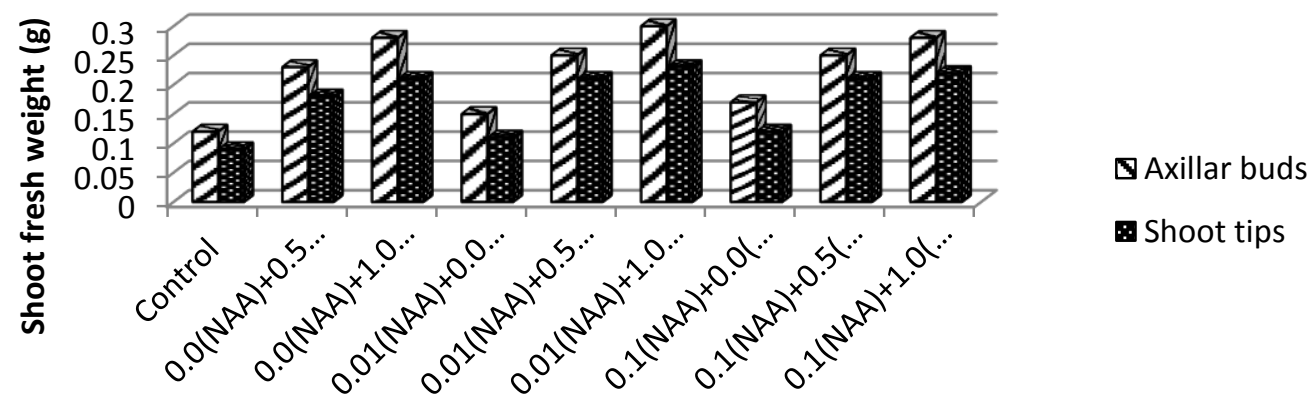

Fig.4 : Effect of MS media supplemented with BA and NAA on shoot fresh weight (g) of Blackberry Prime-Ark 45 cv., at starting stage 


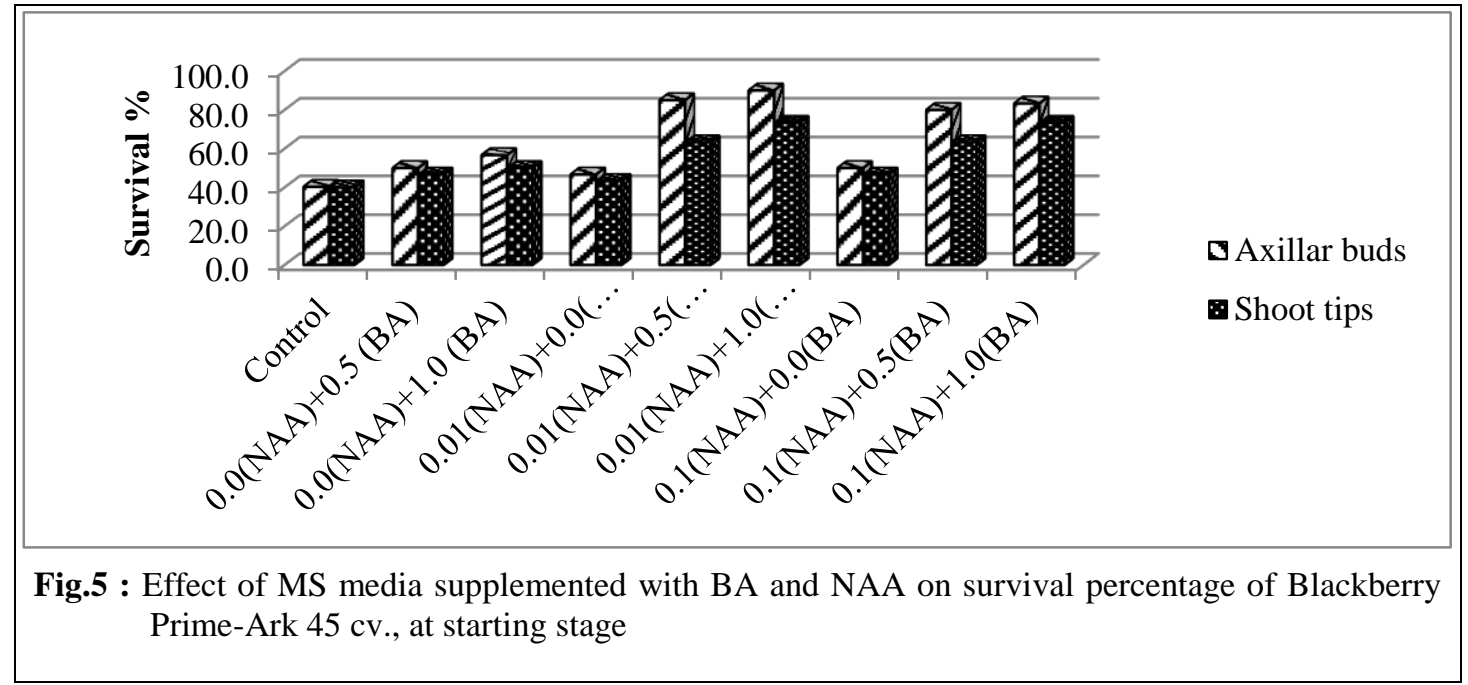

\subsubsection{Multiplication stage.}

Data in Figs. 6 and 8 showed the effect of adding BA and KIN both at $0.0 ; 0.5 ; 1.0$ and $2.0 \mathrm{mg} / \mathrm{L}$ either individually or in combinations to full-strength MS media on some morphogenesis characteristics of Blackberry Prime-Ark 45 cv., such as shoots number; shoot length $(\mathrm{cm})$; leaves number and shoot fresh weight $(\mathrm{g})$. It was clear that adding BA and Kin either individually or in combinations at any concentration to MS media enhanced the morphological characteristics of Prime-Ark 45 Blackberry CV. The results showed that adding BA or KIN at $2.0 \mathrm{mg} / \mathrm{L}$ to MS media individually caused the maximum shoots number and the highest shoot fresh weight $(\mathrm{g})$ of Blackberry Prime-Ark 45 cv., compared with other treatments while the littlest shoots number and shoot fresh weight achieved when micro-shoots were cultured on free MS media. On the other hand, the highest shoot length $(\mathrm{cm})$ and leaves number obtained when the micro-cultures of Prime-Ark $45 \mathrm{cv}$., were cultivated on MS media complemented with low concentration of either BA or KIN $(0.5 \mathrm{mg} / \mathrm{L})$ compared with those of control and other treatments. At the same time, the highest shoots number and shoot fresh weight $(\mathrm{g})$ obtained when micro-shoots were cultured on MS media supplemented with $1.0 \mathrm{mg} / \mathrm{L}$ of both BA and KIN while, adding $0.5 \mathrm{mg} / \mathrm{L}$ of both $\mathrm{BA}$ and KIN possessed the highest value of shoot length $(\mathrm{cm})$ and leaves number of Prime-Ark 45 Blackberry CV compared with those of control and other treatments. These results are in agreement with Villa et al., (2005) who reported that the greater numbers of shoot produced when micro-shoots of blackberry (Rubus sp.)'ÉBANO were cultured on WPM basal medium complemented with $1.0 \mathrm{mg} / \mathrm{l}$ of BA in comparison with those of control and other treatments. While, Najaf-Abadi, and Hamidoghli, (2009) reported that adding $2.0 \mathrm{mg} / \mathrm{L}$ of BA to MS media caused an increase in shoots number of blackberry (Rubus sp.) compared with those of control and other treatments. In tissue cultures as well as in intact plants and plant organs, Cytokinins appear to be necessary for plant cell division. Cytokinins are very effective in promoting direct or indirect shoot initiation. Also, Lepse and Laugale (2008) and Fira et al., (2010) and Fira et al., (2011) propagated blackberry using medium fortified with BA that produced the highest number of shoot per explant. To encourage the growth of axillary buds, and reduce apical dominance in shoot cultures, one or more cytokinins are usually incorporated into the medium at proliferation stage (George et al., 2007). 


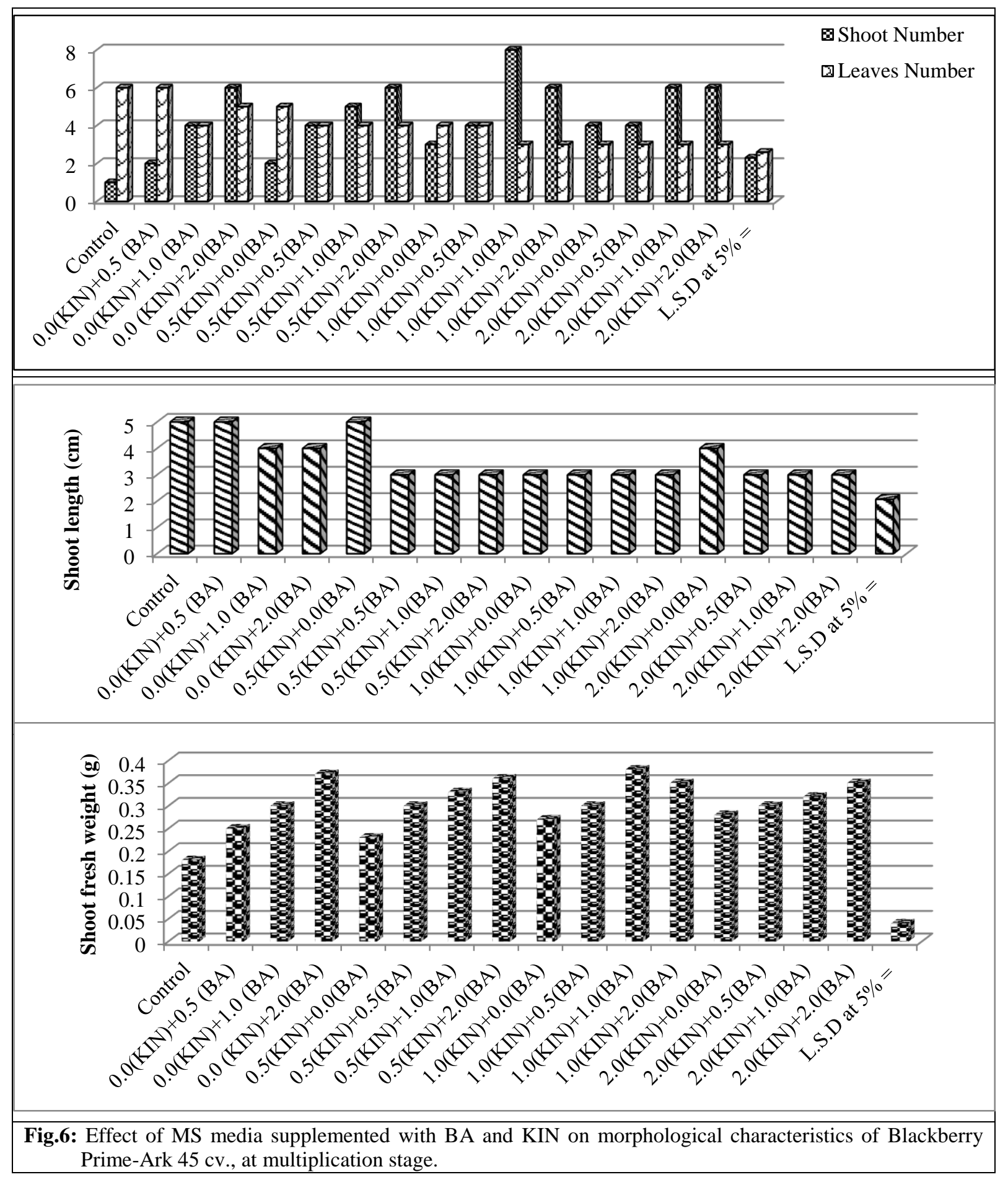

\subsubsection{Rooting stage.}

Data in Figs. 7 and 8 showed the effect of Halfstrength MS media supplemented with $0.0,0.5,1.0$ and $2.0 \mathrm{mg} / \mathrm{L}$ of I both BA and NAA on rooting of Blackberry Prime-Ark 45 cv., growing in vitro. It was clear that, adding Auxins such as IBA and NAA either individually or in combinations to MS media enhanced root formations of Blackberry Prime-Ark 45 cv., compared with control. The highest root formations percentage and roots number were achieved when micro-shoots were cultured on Halfstrength MS media supplemented with $1.0 \mathrm{mg} / \mathrm{L}$ of both IBA and NAA compared with those of control and other treatments. On the hand, the highest root length $(\mathrm{cm})$ obtained when micro-cultures were cultured on MS media complemented with $2.0 \mathrm{mg} / \mathrm{L}$ of NAA individually or obtained when micro-shoots were cultured on MS media supplemented with of both IBA and NAA at 1.0 and $2.0 \mathrm{mg} / \mathrm{L}$ respectively compared with those of control and other treatments. These results are in agreement with Leitzke $\boldsymbol{e t}$ al., (2009) observed that, by increasing the IBA concentration in rooting media there was a reduction in the root length of blackberries and raspberries. 
Finally in acclimatization stage, plants were acclimatized and the percentage of acclimatization reached $85 \%$ when complete-plantlet of Ark 45
Blackberry $\mathrm{CV}$ was cultured in pot contains a mixture of peat; vermiculite and sand 1:1:1 respectively.
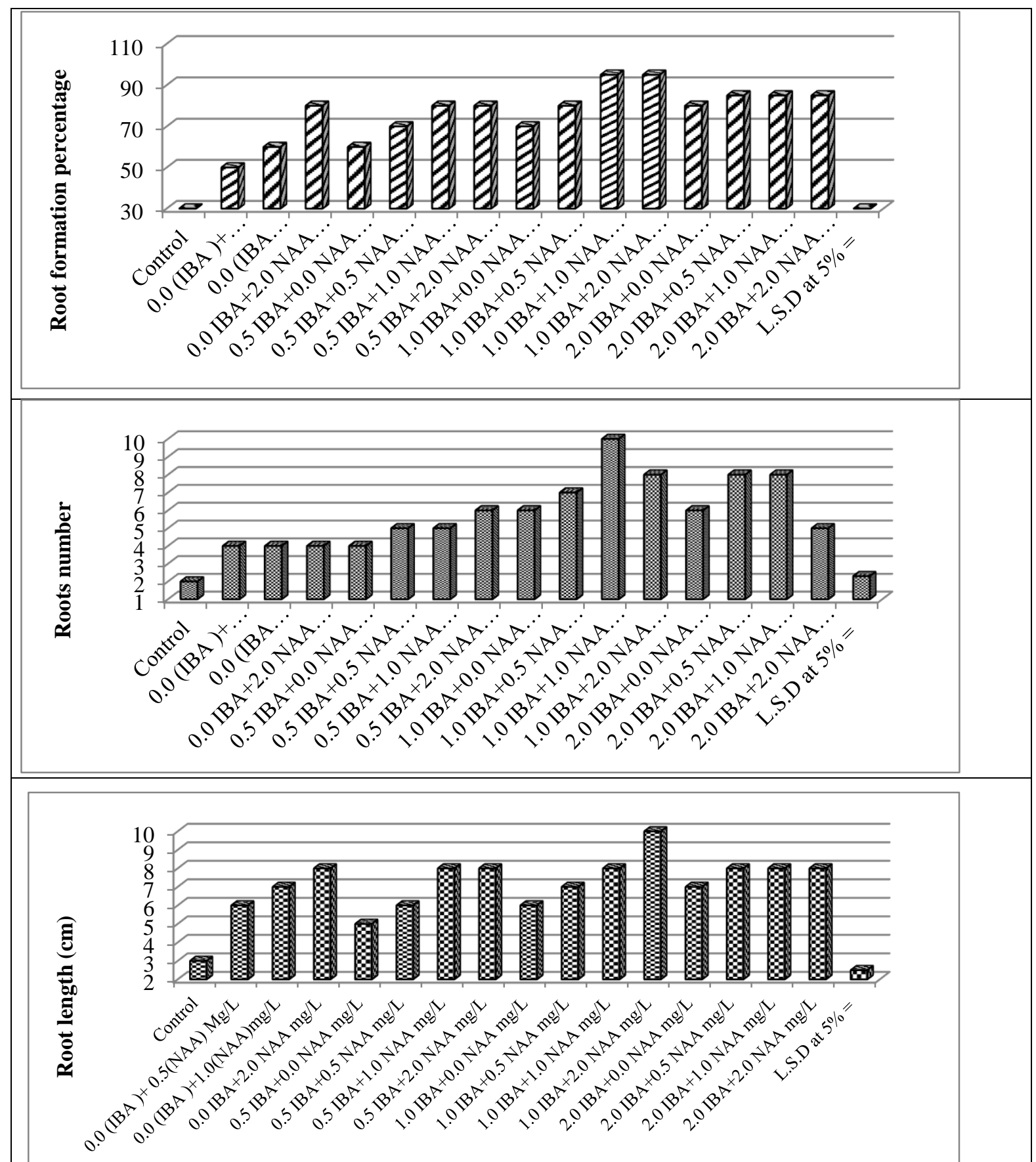

Fig.7: Effect of MS media supplemented with plant growth regulators on morphological characteristics of Blackberry Prime-Ark $45 \mathrm{cv}$., through rooting stage growing In vitro 


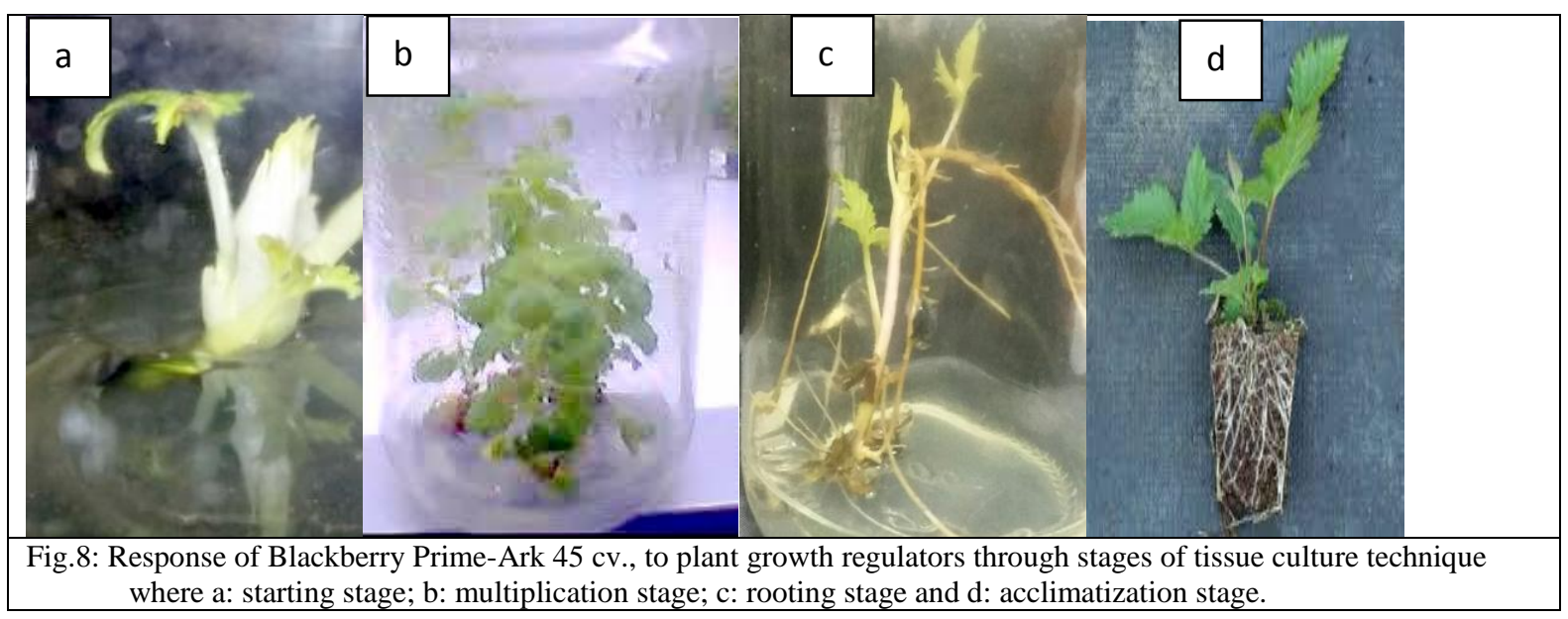

\section{References}

Badr-Elden, A. M., Nower, A. A., Abdallah, A. A and Albeah, H. A. (2016). In Vitro and indirect propagation of blackberry (RUBUS SP.). Research Journal of Applied Biotechnology, 2(Special issue (2) for the first International Conference of Genetic Engineering and Biotechnology), 89-100.

Busby, A. L., and Himelrick, D. G. (1998, January). Propagation of blackberries (Rubus spp.) by stem cuttings using various IBA formulations. In VII International Symposium on Rubus and Ribes 505 (pp. 327-332)

Carter, P.M; Clark. J.R; Par- ticka. C.D. and Crowne.D.Y. (2006). Chilling Response of Arkansas Blackberry Cultivars. Journal of the American Pomological Scity, Vol 60 (4): 187-197.

Farag, A. A. M., Yahia, I. S., Wojtowicz, T and Karczewski, G. (2010). Influence of temperature and illumination on the electrical properties of $\mathrm{p}$ $\mathrm{ZnTe} / \mathrm{n}-\mathrm{CdTe}$ heterojunction grown by molecular beam epitaxy. Journal of Physics D: Applied Physics, 43(21), 215102.

Fira, A., D. Clapa and Plopa. C (2010). New Aspects Regarding the Micropropagation of Blackberry Cultivar, Thornless evergreen. Bulletin UASVM Horticulture, 67(1):106-114.

Fira, A., D. Clapa and RakosyTican. E. ( 2011). In Vitro Propagation of the Thornless Blackberry Cultivar 'Loch Ness. Bulletin UASVM Horticulture, 68 (1): $39-46$

Fira, A., Clapa, D., and Simu, M. (2014). Studies regarding the micropropagation of some blackberry cultivars. Bulletin of University of Agricultural Sciences and Veterinary Medicin Cluj-Napoca. Horticulture, 71(1), 29-37.

George, A. J ;Yates, A., Chan, C., Strid, J., Moon, S., Callard, $R$ and Stark, J. (2007). Reconstruction of cell population dynamics using CFSE. BMC bioinformatics, 8(1), 196.

Hall, H.K. (1990) Blackberry breeding, In: J. Janick (Ed.). Plant Breeding Reviews. Timber Press, Inc, Portland, OR, pp. 249-312.

Leitzke, L.N; Damiani .C.R., and . Schuch. M.W ( 2009). Meio de cultura, concentração de AIB e tempo de cultivo no enraizamento in vitro de amoreira-preta e framboeseira. Rev. Bras. Frutic. 31(2), 582-587. Doi: 10.1590/ S0100-29452009000200037

Lepse. L. and Laugale. V, (2008). Micropropagation, rooting and acclimatization of blackberry "Agavam". 1International Symposium on Biotechnology of fruit species: BIOTECH FRU 2008

Meng, R;Chen, T. H; Finn, C. E and Li, Y. (2004). Improving In Vitro Plant Regeneration from Leaf and Petiole Explants ofMarion'Blackberry. HortScience, 39(2), 316-320.

Najaf-Abadi, A. J and Hamidoghli. Y, (2009). Micropropagation of Thornless Trailing Blackberry ('Rubus sp.') by Axillary Bud Explants. Australian Journal of Crop Science, 3(4), 191.

Ružić, D and Lazić, T. (2006). Micropropagation as means of rapid multiplication of newly developed blackberry and black currant cultivars. Agriculturae Conspectus Scientificus, 71(4), 149-153.

Shen, X. S., Wan, J. Z and Luo, W. Y. (1990). Propagation in vitro of Chinese gooseberry

(Actinidia chinensis) through the development of axillary buds. Scientia Horticulturae, 42(1-2) 45-54.

Siriwoharn, T., Wrolstad, R. E., Finn, C. E and Pereira, C. B. (2004). Influence of cultivar, maturity, and sampling on blackberry (Rubus L. Hybrids) anthocyanins, polyphenolics, and antioxidant properties. Journal of Agricultural and Food Chemistry, 52(26), 8021-8030.

Stern, R. D. (1991). Review of'Co-Stat-Statistical Software'Experimental Agriculture, 27.

Taiz, L. and Zeiger. E,( 2013). Fisiologia vegetal. 5th ed. Artmed, Porto Alegre, Brazil

Villa, F., Araújo, A. G. D., Pio, L. A. S and Pasqual, M. (2005). In vitro multiplication of

blackberry (Rubus sp.)'ÉBANO'in diferents MS medium concentrations and BAP. Ciência e Agrotecnologia, 29(3), 582-589.

Yazzetti, D., Clark, J. R and Stafne, E. T (2001). Evaluating the usage of stem cuttings to determine chilling requirements in six Arkansas blackberry cultivars. Hort Studies, 40-41. 